\title{
Generation of Electricity by Electrogenic Bacteria in a Microbial Fuel Cell Powered by Waste Water
}

\author{
Zakira Naureen*, Zainab Ali Rashid Al Matani, Miyassa Nasser Al Jabri, \\ Saif Khalfan Al Housni, Syed Abdullah Gilani, Fazal Mabood, Saima Farooq, \\ Javid Hussain, Ahmed Al Harrasi \\ Department of Biological Science and Chemistry, University of Nizwa, Nizwa, Oman \\ Email: "zakira@unizwa.edu.om
}

Received 27 September 2015; accepted 14 October 2015; published 7 July 2016

Copyright (C) 2016 by authors and Scientific Research Publishing Inc.

This work is licensed under the Creative Commons Attribution International License (CC BY). http://creativecommons.org/licenses/by/4.0/

(c) (i) Open Access

\section{Abstract}

The present study aimed at isolation characterization and evaluation of electrogenic bacteria for electricity generation using waste water. In this context, waste water samples were collected from University of Nizwa waste water treatment plant. A total of eight distinct bacterial isolates were isolated from these samples by serial dilution and plating on LB Agar medium. The bacterial isolates were than grown at different temperatures and $\mathrm{pH}$. DNA from bacterial samples was isolated and 16S rRNA gene amplification was carried out. The 16S rRNA gene PCR products were directly sequenced and the resulting sequence was blasted using BLASTn. Based on BLAST results, the bacterial strains were identified. The bacteria were used in different combinations to generate electricity from waste water in microbial fuel cells constructed using plastic bottles. The microbial isolates were found to produce varying levels of currents and their electrogenic potential in waste water was observed to increase with the passage of time.

\section{Keywords}

Electricity Production, Electrogenic Bacteria, Waste Water, Microbial Fuel Cell

\section{Introduction}

The world energy demand and the corresponding need to find energy sources alternative to fossil fuels are on an ongoing increase. Microbial Fuel Cell (MFC technology) powered by wastewater is one such effort to provide

${ }^{*}$ Corresponding author.

How to cite this paper: Naureen, Z., Al Matani, Z.A.R., Al Jabri, M.N., Al Housni, S.K., Gilani, S.A., Mabood, F., Farooq, S., Hussain, J. and Al Harrasi, A. (2016) Generation of Electricity by Electrogenic Bacteria in a Microbial Fuel Cell Powered by Waste Water. Advances in Bioscience and Biotechnology, 7, 329-335. http://dx.doi.org/10.4236/abb.2016.77031 
an alternative inexpensive and eco-friendly energy source [1] [2]. Besides generating energy, MFCs offer a great potential to utilize chemical energy in wastewater by converting to electrical energy through respiration of microbial inhabitants of wastewater [2]. Wastewater is an energy rich source for growth of several anaerobic and facultative bacterial species which have the capability to transfer electrons to an anode, as a terminal electron acceptor and thus are classified as electrogenic bacteria (EB; [3]-[6]). These EB have been documented to generate electricity by assimilating a variety of sources [7]-[10] like carbohydrates [11], textile effluents [12], waste matter in land fill [1], sea sediments and waste water [1]; however a very few reports are available where waste water is used as fuel for electrogenic bacteria which utilize organic and inorganic compounds in it as fuel to generate electricity. The present study will focus on electrogenic potential of facultative anaerobic bacteria to generate the electricity in a fabricated two-chambered MFC powered by waste water.

\section{Material and Methods}

\subsection{Collection of Samples}

The waste water samples were collected in sterile containers from University of Nizwa. The samples were stored at $4^{\circ} \mathrm{C}$ for further studies.

\subsection{Isolation of Bacteria from Waste Water Sediments}

The waste water samples were allowed to stand for 24 hours and the sediments were collected and serially diluted with saline water $(0.9 \% \mathrm{w} / \mathrm{v} \mathrm{NaCl})$ up to $10^{-5}$ dilutions. From each dilution $0.1 \mathrm{~mL}$ was then spread on the LB agar plate (Tryptone $10.0 \mathrm{~g}, \mathrm{NaCl} 10.0 \mathrm{~g}$, Agar $20.0 \mathrm{~g}$ and Yeast extract $5.0 \mathrm{~g}$ in $1000 \mathrm{~mL}$ distilled water) and incubated for $24 \mathrm{~h}$ at $30^{\circ} \mathrm{C}$. Morphologically distinct bacterial colonies were purified and further studied for their Gram staining properties [13].

\subsection{Physiochemical Growth Optimization of Bacteria}

The morphologically distinct colonies were further inoculated in LB broth and kept at different $\mathrm{pH}$ [13] [14] and different temperature $\left(27^{\circ} \mathrm{C}, 37^{\circ} \mathrm{C}, 47^{\circ} \mathrm{C}\right.$ and $\left.57^{\circ} \mathrm{C}\right)$ in an orbital shaker to study the growth pattern of these bacteria by measuring absorption at $660 \mathrm{~nm}$, against the sterile LB broth as blank [14] using an ELISA reader. These bacterial isolates were further inoculated in waste water samples and then their growth parameters were recorded and compared with that in LB broth. The best surviving bacterial strains were used further in MFCs.

\subsection{Electricity Generation and Identification of Potent Electrogenic Bacteria}

After optimizing growth and MFC parameters, the isolates were studied for their electrogenicity within $500 \mathrm{~mL}$ LB broth culture (24 h old) as anolyte against $500 \mathrm{~mL}$ waste water solution as catholyte. Electrogenicity were recorded in terms of OCV. The potentially active electrogenic bacteria were identified using 16S rRNA gene cloning, sequencing and analysis using MEGA blast [15].

\subsection{MFC Fabrication and Operation}

Two polycarbonate bottles (500 mL) were used to construct an H-shaped MFCs. The bottles were linked with PVC pipes of various lengths such as $(5 \mathrm{~cm} \times 1 \mathrm{~cm} ; 10 \mathrm{~cm} \times 2 \mathrm{~cm}$ etc.) for preparing a salt bridge. The salt bridges were filled by boiled cooled sodium chloride (15\%) solution containing $5 \%$ agar. The salt bridges were fixed to the bottles with the aid of epoxy adhesive. The waste water cultures of selected bacterial strains were used as anolyte without any pretreatment and various concentrations of waste water were used as a catholyte in the MFC setups. Plain graphite plates $\left(5-5 \mathrm{~cm} ; 10 \mathrm{~mm}\right.$ thick; surface area, $70 \mathrm{~cm}^{2}$ ) were used as electrodes. Circuit connections were set with the copper wires fixed into the drilled holes of the electrodes and sealed with epoxy resin to avoid corrosion of copper wire [12].

The MFCs were sterilized by thorough rinsing with Ethanol $(70 \% \mathrm{v} / \mathrm{v})$ and UV irradiated for $30 \mathrm{~min}$. The sterilized MFC chambers were filled with respective electrolytes and kept at room temperature $28^{\circ} \mathrm{C} \pm 2^{\circ} \mathrm{C}$ for one day. Electricity generation was recorded using a multidigital meter (UNI-DT830D, Uni-Trend Group Ltd., Kowloon, Hong Kong) after 1, 7 and 21 days. 


\section{Results}

Waste water samples were collected from UoN waste water treatment plant and allowed to stand for 24 hrs. The sediments were collected and diluted and directly plated on respective media for isolation of inhabiting bacteria. The morphologically distinct colonies were selected for further studies.

\subsection{Determination of Phenotypic Characteristics}

\section{Gram Staining}

Out of 8 distinct bacterial isolates screened 7 were Gram negative and one was Gram positive. All bacterial strains were catalase positive and facultative anaerobes (Table 1).

\subsection{Bacterial Growth Optimization at Different Temperatures}

The isolates were grown for 7 days at $27^{\circ} \mathrm{C}, 30^{\circ} \mathrm{C}, 37^{\circ} \mathrm{C}$, and $55^{\circ} \mathrm{C}$. We observe that most of isolates were able to grow at $27^{\circ} \mathrm{C}$ and the other isolates were able to grow best at $37^{\circ} \mathrm{C}$, and weak observations of growth were taken at $30^{\circ} \mathrm{C}$ and $55^{\circ} \mathrm{C}$. Four reading were taken with three replications for each isolates to calculate the number of cells as shown in Table 2.

\subsection{Bacterial Growth Optimization at Different pH}

The isolates were grown for 7 days at $\mathrm{pH}$ 4, 5, 9 and 11 respectively. We observe that most of isolates were able to grow at $\mathrm{pH} 5$ while other isolates were able to grow best at $\mathrm{pH}$ 9. Weak o growth of bacteria was observed at pH 4 and pH 11. For each isolate four readings were recorded with three replications to calculate the number of cells as shown in Table 3.

\subsection{Identification of Isolates by 16S rRNA}

16S rRNA was performed for all isolates. The forward primer was complementary to the 5'-end of 16S rRNA and the reverse primer was complementary to 3'- of the 16S rRNA (Young et al., 1991). The amplified PCR products were cleaned and directly sequenced. The obtained sequence was trimmed, chimera removed and blasted on BLAST $n$ of NCBI. The bacterial species were identified on the basis of maximum similarity with known genera and then the sequences were submitted to Genbank and accession numbers were obtained.

Table 1. Physiological characteristics and 16S rRNA gene sequencing based identification of bacterial isolates obtained from waste water samples.

\begin{tabular}{|c|c|c|c|c|c|}
\hline Sequences & Strain ID & Identification & Gram staining & Respiration & Accession numbers \\
\hline seq1 & $\mathrm{Z} 1$ & Chromobacterium sp. 1 & Gram negative & $\begin{array}{c}\text { Facultative } \\
\text { anaerobic }\end{array}$ & КT347176 \\
\hline seq2 & $\mathrm{Z} 2$ & Amantichitinum ursilacus & Gram negative & $\begin{array}{c}\text { Facultative } \\
\text { anaerobic }\end{array}$ & КТ347177 \\
\hline seq3 & $\mathrm{Z3}$ & Chromobacterium sp & Gram negative & $\begin{array}{c}\text { Facultative } \\
\text { anaerobic }\end{array}$ & КT347178 \\
\hline seq4 & $\mathrm{Z} 4$ & Bacillus licheniformis & Gram positive & $\begin{array}{c}\text { Facultative } \\
\text { anaerobic }\end{array}$ & КТ347179 \\
\hline seq5 & $\mathrm{Z5}$ & Enterobacter sp & Gram negative & $\begin{array}{c}\text { Facultative } \\
\text { anaerobic }\end{array}$ & КТ347180 \\
\hline seq6 & Z6 & Unidentified bacteria & Gram negative & $\begin{array}{c}\text { Facultative } \\
\text { anaerobic }\end{array}$ & NOT IDENTIFIED \\
\hline seq7 & $\mathrm{Z7}$ & Escherichia coli & Gram negative & $\begin{array}{c}\text { Facultative } \\
\text { anaerobic }\end{array}$ & КT347181 \\
\hline seq8 & $\mathrm{Z8}$ & Citrobacter sp. & Gram negative & $\begin{array}{c}\text { Facultative } \\
\text { anaerobic }\end{array}$ & КT347182 \\
\hline
\end{tabular}


Table 2. Bacterial growth at different temperatures.

\begin{tabular}{|c|c|c|c|c|c|c|c|c|}
\hline \multirow[b]{2}{*}{ Temperature } & \multicolumn{8}{|c|}{ Bacterial isolates } \\
\hline & $\begin{array}{l}\text { Chromobacterium } \\
\text { sp. } 1 \mathrm{Z1}\end{array}$ & $\begin{array}{l}\text { Amantichitinum ursilacus } \\
\text { Z2 }\end{array}$ & $\begin{array}{c}\text { Chromobacterium } \\
\text { sp. Z3 }\end{array}$ & $\begin{array}{c}\text { Bacillus } \\
\text { licheniformis } \\
\text { Z4 }\end{array}$ & $\begin{array}{l}\text { Enterobacter } \\
\text { sp. Z5 }\end{array}$ & $\begin{array}{l}\text { Unidentified } \\
\text { bacteria Z6 }\end{array}$ & $\begin{array}{l}\text { Escherichia } \\
\text { coli Z7 }\end{array}$ & $\begin{array}{l}\text { Citrobacter } \\
\text { sp. Z8 }\end{array}$ \\
\hline $27^{\circ} \mathrm{C}$ & $1.53 \times 10^{9}$ & $1.25 \times 10^{9}$ & $1.07 \times 10^{9}$ & $1.55 \times 10^{9}$ & $3.0 \times 10^{9}$ & $3.26 \times 10^{8}$ & $2.96 \times 10^{9}$ & $1.49 \times 10^{9}$ \\
\hline $30^{\circ} \mathrm{C}$ & $1.36 \times 10^{9}$ & $7.26 \times 10^{8}$ & $1.28 \times 10^{9}$ & $1.57 \times 10^{9}$ & $6.24 \times 10^{8}$ & $7.34 \times 10^{8}$ & $7.28 \times 10^{8}$ & $1.43 \times 10^{9}$ \\
\hline $37^{\circ} \mathrm{C}$ & $1.45 \times 10^{9}$ & $5.3 \times 10^{8}$ & $1.34 \times 10^{9}$ & $1.42 \times 10^{9}$ & $2.98 \times 10^{8}$ & $3.52 \times 10^{8}$ & $3.99 \times 10^{8}$ & $1.6 \times 10^{9}$ \\
\hline $55^{\circ} \mathrm{C}$ & $6.32 \times 10^{8}$ & $2.25 \times 10^{8}$ & $6.02 \times 10^{8}$ & $6.01 \times 10^{8}$ & $2.55 \times 10^{8}$ & $2.57 \times 10^{8}$ & $2.64 \times 10^{8}$ & $1.11 \times 10^{9}$ \\
\hline
\end{tabular}

Table 3. Bacterial growth at different $\mathrm{pH}$.

\begin{tabular}{|c|c|c|c|c|c|c|c|c|}
\hline \multirow[t]{2}{*}{$\mathrm{pH}$} & \multicolumn{8}{|c|}{ Bacteria isolates } \\
\hline & $\begin{array}{l}\text { Chromobacterium } \\
\text { sp. } 1 \mathrm{Z} 1\end{array}$ & $\begin{array}{l}\text { Amantichitinum ursilacus } \\
\text { Z2 }\end{array}$ & $\begin{array}{l}\text { Chromobacterium } \\
\text { sp. Z3 }\end{array}$ & $\begin{array}{c}\text { Bacillus } \\
\text { licheniformis } \\
\text { Z4 }\end{array}$ & $\begin{array}{l}\text { Enterobacter } \\
\text { sp. Z5 }\end{array}$ & $\begin{array}{l}\text { Unidentified } \\
\text { bacteria Z6 }\end{array}$ & $\begin{array}{l}\text { Escherichia } \\
\text { coli Z7 }\end{array}$ & $\begin{array}{c}\text { Citrobacter sp } \\
\text { Z8 }\end{array}$ \\
\hline 4 & $1.20 \times 10^{9}$ & $1.03 \times 10^{8}$ & $5.37 \times 10^{8}$ & $1.03 \times 10^{8}$ & $1.51 \times 10^{8}$ & $3.26 \times 10^{8}$ & $1.32 \times 10^{8}$ & $1.31 \times 10^{8}$ \\
\hline 5 & $3.75 \times 10^{8}$ & $1.26 \times 10^{9}$ & $1.17 \times 10^{8}$ & $7.08 \times 10^{8}$ & $9.32 \times 10^{8}$ & $1.31 \times 10^{8}$ & $2.87 \times 10^{8}$ & $5.35 \times 10^{8}$ \\
\hline 9 & $5.37 \times 10^{8}$ & $7.34 \times 10^{8}$ & $1.03 \times 10^{8}$ & $1.65 \times 10^{9}$ & $5.35 \times 10^{8}$ & $3.52 \times 10^{8}$ & $1.60 \times 10^{9}$ & $1.6 \times 10^{9}$ \\
\hline 11 & $1.11 \times 10^{8}$ & $3.75 \times 10^{8}$ & $1.43 \times 10^{8}$ & $1.36 \times 10^{9}$ & $1.88 \times 10^{8}$ & $2.57 \times 10^{8}$ & $3.35 \times 10^{8}$ & $6.47 \times 10^{8}$ \\
\hline
\end{tabular}

\subsection{Sequences Analyses and Phylogenic Study}

The data was set, aligned, curetted, and phylogeny program shown (Figure 1). Sequence analysis through BLAST search identified seven of the total eight bacterial strains as Chromobacterium sp. (two strains Z1 and Z3), Amantichitinum ursilacus (Z2), Bacillus licheniformis (Z4), Citrobacter (Z8), Escherichia coli (Z7), and Enterobacter sp. (Z5) while one of the bacterial strains remained unidentified (Z6).

As the phylogenetic tree shows, the isolates were divided into two major groups and five subgroups, the members of one of the subgroups (Chromobacterium sp.) were 100\% related to each other. Both the Chromobacterium sp. Z1 \& Z3 were grouped together because they had higher sequence similarity. However, Amantichitinum ursilacus Z2 and Bacillus licheniformis also sub-clustered with Chromobacterium sp. The Citrobacter sp. Z8 was separated from rest of all the bacterial strains showing that it has a low conservative sequence. In a second sub-cluster, Enterobacter sp. Z5, Escherichia coli Z7 and unidentified bacteria were grouped together. In the second sub-cluster, unidentified bacterium was separated from the group which shows that its 16S rRNA sequence had more nucleotide variations.

For constructing the tree FASTA sequences were first aligned using Clustal Omega and then submitted to MEGA 5 (Bootstrap number 1000).

\subsection{MFC Fabrication and Operation}

Microbial fuel cells were operated with different anode and cathode compositions and with different salt bridges. The best results were obtained for $\mathrm{NaCl}$ salt bridge of $10 \mathrm{~cm}$ length. Different bacterial isolates showed varying level of electricity generation when tested against varying concentration of waste water. The best results were obtained for $50 \%$ wastewater concentration. Highest electric current at 0 days was observed for bacterial isolate Enterobacter sp. Z5 (Table 4). The Microbial fuel cells were than left at room temperature $\left(30^{\circ} \mathrm{C}\right)$ for 7 days after which OCV were recorded again. An increase in OCV was observed for all bacterial isolates with Chromobacterium sp.1 Z1, Amantichitinum ursilacus Z2 and Enterobacter sp. Z5 showing high levels of electric currents. The bacterial isolates in the respective fuel cells were further allowed to respire in the MFCs for 21 days. Tremendous increase in electricity generation was observed for all bacterial strains with highest being observed for Amantichitinum ursilacus Z2. 


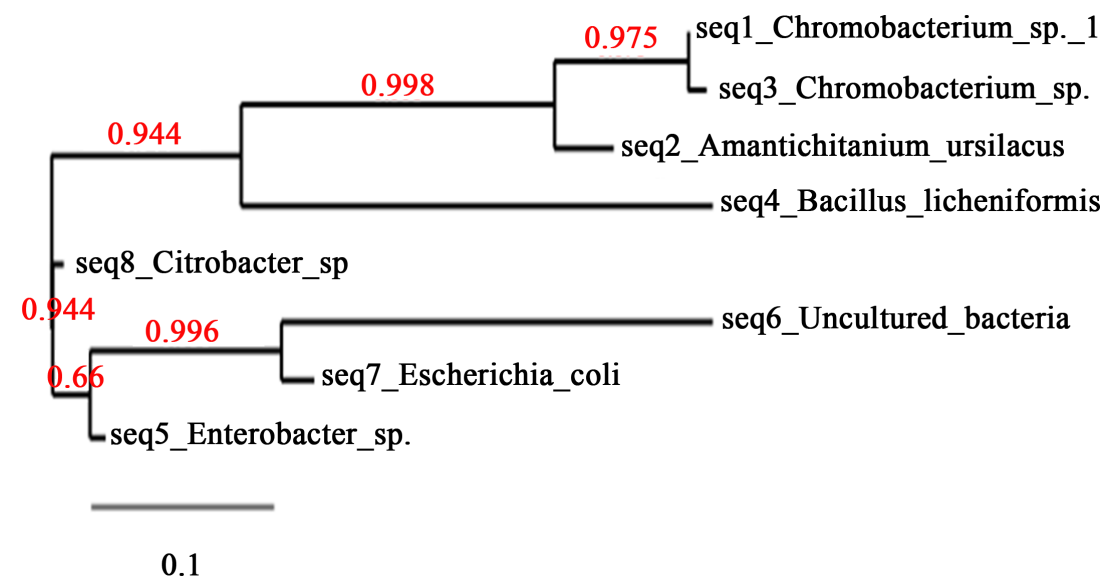

Figure 1. Phylogenetic analysis of bacterial isolates.

Table 4. Electricity production by bacterial isolates at different days.

\begin{tabular}{cccc}
\hline \multirow{2}{*}{ Bacteria isolates } & \multicolumn{3}{c}{ Electricity production } \\
\cline { 2 - 4 } & First trial (mV) 1 days & Second trial (mV) 7 days & Third trial (mV) 21 days \\
\hline Chromobacterium sp. 1 (Z1) & 86 & 141 & 430 \\
Amantichitinum ursilacus (Z2) & 37 & 143 & 645 \\
Chromobacterium sp. (Z3) & 63 & 66 & 230 \\
Bacillus licheniformis (Z4) & 10 & 16 & 222 \\
Enterobacter sp. (Z5) & 114 & 135 & Not detected \\
Unidentified bacteria (Z6) & 67 & 72 & 625 \\
Escherichia coli (Z7) & 29 & 78 & 460 \\
Citrobacter sp. (Z8) & 16 & 17 & \\
\hline
\end{tabular}

\section{Discussion}

The present study states that microbial inhabitant of waste water have electrogenic potential and they can manifest this potential if they are properly re-inoculated into their habitat. This leads to the production of bioelectricity in the fabricated MFCs. A total of 8 distinct bacterial isolates from waste water sediments were isolated and their 16S rRNA gene sequence analysis showed that these belong to different genera. Bacterial isolate 6 did not show specific resemblance to any known genera suggesting that it might be novel specie/genera. This will be further studied by whole genome sequence analysis coupled with biochemical identification methods. Microbial fuel cells constructed by using $1000 \mathrm{ml}$ PVC bottles and connected with $15 \mathrm{~cm}$ long and $4 \mathrm{~cm}$ diameter salt bridge were used to generate electricity by microbial cell suspension cultures in various concentrations of waste water. Microbial cultures served as anodes while waste water concentrations served as cathodes. This analysis of different salts for the Salt Bridge recommended the use of $10 \% \mathrm{NaCl}$ concentration as optimized salt in the salt bridge to facilitate easy ion flux. The sodium chloride in the salt bridge yielded good OCV might be because of its good electrolytic property [16]. While $15 \mathrm{~cm}$ length of salt bridge proved better with $4 \mathrm{~cm}$ diameter might be because of less density of agar in longer length and easy flow ions through wider diameter. This result is supported by similar observations by other researchers [16]. It was reported that most of the exogenous mediators are toxic for the microbes [2]. Electricity generation from the 100\% wastewater could not produce good yield might be effect of ions present in both the electrolytes. An increase in the OCV was observed for all bacterial isolates after 7 and 21 days of incubation suggesting that high flow of electrons through salt bridge with increasing time period. The OCV of $645 \mathrm{mV}$ was generated by the isolate Amantichitinum ursilacus (Z2) was nearer to that of maximum OCV of $800 \mathrm{mV}$ [16] reported until now. This implies that the bacterial isolate Amantichitinum ursilacus (Z2) might have electrogenic properties like C-type cytochromes [17] or conductive 
nano-wires [18] on its cell membrane to generate electric potential [19].

The electrogenic potential of these bacteria may be attributed to their ability to adapt to different $\mathrm{pH}$ and different temperatures. For instance most of the bacterial isolates grew well at $30^{\circ} \mathrm{C}$ and this might be the reason for increase in electrogenic potential of these bacteria when they were left in MFC at a room temperature of $30^{\circ} \mathrm{C}$. It has been previously demonstrated that the power density of MFCs is seriously affected by operation temperatures. For instance the conductivity was reported to increase by $2 \%{ }^{\circ} \mathrm{C}^{-1}$ which could be attributed to increase in the activity of anode microorganisms, distribution proportion of nutrients, growth of electrochemically active microbes, conductivity of electrolyte and chemical reaction rate [20]. Therefore, an increase in temperature results in decrease in the internal resistance of MFC thus minimizing the energy loss and resulting in an increase in electrogenic potential of the system [21]. Moreover different bacterial isolates had different electrogenic processes, some strains were capable of producing electricity rapidly (Z5) while others enriched slowly and showed an increase in electricity generation after 7 \& 21 days (Z2 \& Z7). It was probably because Z5 had fast growth rate and adhered to electrode rapidly [21].

\section{Conclusion}

The present study revealed that the potential electrogenic bacteria can be easily procured from waste water sediments and deployed in MFCs for an eco-friendly and economically viable method of electricity generation. Bacterial isolates Z2 \& Z7 can be further utilized to generate electricity from waste water. Bacterial isolate Z6 might prove to be potentially novel specie/genera and will be further investigated using conventional and modern microbial identification methods.

\section{Acknowledgements}

The present research has received FURAP Research Grant Funding from the Research Council of the Sultanate of Oman (TRC). The authors would like to acknowledge support from TRC.

\section{References}

[1] Khanal, S.K. (2008) Anaerobic Biotechnology for Bioenergy Production: Principles and Applications, John Wiley and Sons Inc., Iowa. http://dx.doi.org/10.1002/9780813804545

[2] Rabaey, K., Lissens, G., Siciliano, S.D. and Verstraete, W. (2003) A Microbial Fuel Cell Capable of Converting Glucose to Electricity at High Rate and Efficiency. Biotechnology Letters, 25, 1531-1535. http://dx.doi.org/10.1023/A:1025484009367

[3] Liu, H. and Logan B.E. (2004) Electricity Generation Using an Air Cathode Single Chambers Microbial Fuel Cell in the Presence and Absence of a Proton Exchange Membrane. Environmental Science \& Technology, 38, 4040-4046. http://dx.doi.org/10.1021/es0499344

[4] Rabaey, K., Rodríguez, J., Blackall, L.L., Keller, J., Gross, P., Batstone, D., et al. (2007) Microbial Ecology Meets Electrochemistry: Electricity-Driven and Driving Communities. The ISME Journal, 1, 9-18. http://dx.doi.org/10.1038/ismej.2007.4

[5] Logan, B.E., Hamelers, B., Rozendal, R., Schroder, U., Keller, J., Freguia, S., et al. (2006) Microbial Fuel Cells: Methodology and Technology. Environmental Science \& Technology, 40, 5181-5192. http://dx.doi.org/10.1021/es0605016

[6] Rabaey, K., Boon, N., Siciliano, S.D., Verhaege, M. and Verstraete, W. (2004) Biofuel Cells Select for Microbial Consortia That Self-Mediate Electron Transfer. Applied and Environmental Microbiology, 70, 5373-538. http://dx.doi.org/10.1128/AEM.70.9.5373-5382.2004

[7] Logan, B.E. (2008) Microbial Fuel Cells. John Wiley \& Sons, Inc., New York.

[8] Lovley, D.R. (2006) Bug juice: Harvesting Electricity with Microorganisms. Nature Reviews Microbiology, 4, 497-508. http://dx.doi.org/10.1038/nrmicro1442

[9] Richter, H., Lanthier, M., Nevin, K.P. and Lovley, D.R. (2007) Lack of Electricity Production by Pelobacter carbinolicus Indicates That the Capacity for Fe(III) Oxide Reduction Does Not Necessarily Confer Electron Transfer Ability to Fuel Cell Anodes. Applied and Environmental Microbiology, 73, 5347-5353. http://dx.doi.org/10.1128/AEM.00804-07

[10] Bretschger, O., Obraztsova, A., Sturm, C.A., Chang, I.S., Gorby, Y.A., Reed, S.B., et al. (2007) Current Production and Metal Oxide Reduction by Shewanellaoneidensis MR-1 Wild Type and Mutants. Applied and Environmental Microbiology, 73, 7003-7012. http://dx.doi.org/10.1128/AEM.01087-07 
[11] Allen, R.M. and Bennetto, H.P. (1993) Microbial Fuel Cells: Electricity Production from Carbohydrates. Applied Biochemistry and Biotechnology, 39, 27-40. http://dx.doi.org/10.1007/BF02918975

[12] Zou, Y.J., Sun, L.X., Fen, X.U. and Yang, L.N. (2007) E. coli Microbial Fuel Cell Using New Methylene Blue as Electron Mediator. Chemical Journal of Chinese Universities, 28, 510-513.

[13] Smibert, R.M. and Krieg, N.R. (1994) Phenotypic Characterization. In: Gerhardt, P., Murray, R.G.E., Wood, W.A. and Krieg, N.R., Eds., Methods for General and Molecular Bacteriology, American Society for Microbiology, Washington DC, 607-654.

[14] Safia, M., Xama, K. and Madamwar, D. (2007) Isolation, Characterization and Decolorization of Textile Dyes by a Mixed Bacterial Consortium JW-2. Dyes and Pigments, 74, 723-729. http://dx.doi.org/10.1016/j.dyepig.2006.05.005

[15] Naureen, Z., Hafeez, F.Y., Hussain, J., Al Harrasi, A., Bouqellah, N. and Roberts, M.R. (2015) Suppression of Incidence of Rhizoctonia solani in Rice by Siderophore Producing Rhizobacterial Strains Based on Competition for Iron. European Scientific Journal, 11, 186-207. http://eujournal.org/index.php/esj/article/view/4997

[16] Liu, H., Cheng, S. and Logan, B.E. (2005) Production of Electricity from Acetate or Butyrate Using a Single-Chambers Microbial Fuel Cell. Environmental Science \& Technology, 39, 658-662. http://dx.doi.org/10.1021/es048927c

[17] Kim, H.J., Park, H.S., Hyun, M.S., Chang, I.S., Kim, M. and Kim, B.H. (2002) A Mediator-Less Microbial Fuel Cell Using a Metal Reducing Bacterium, Shewanella putrefaciens. Enzyme and Microbial Technology, 30, 145-152. http://dx.doi.org/10.1016/S0141-0229(01)00478-1

[18] Gorby, Y.A., Yanina, S., McLean, J.S., Rosso, K.M., Moyles, D., Dohnalkova, A., et al. (2006) Electrically Conductive Bacterial Nanowires Produced by Shewanellaoneidensis Strain MR-1 and Other Microorganisms. Proceedings of the National Academy of Sciences of the United States of America, 103, 11358-11363. http://dx.doi.org/10.1073/pnas.0604517103

[19] Strycharz-Glaven, S.M., Snider, R.M., Anthony, G. and Tender, L.M. (2011) On the Electrical Conductivity of Microbial Nanowires and Biofilms. Energy \& Environmental Science, 4, 4366-4379. http://dx.doi.org/10.1039/c1ee01753e

[20] Rahimnejad, M., Adhami, A., Darvari, S., Zirepour, A., and Oh, S.E. (2015) Microbial Fuel Cell as New Technology for Bioelectricity Generation: A Review. Alexandria Engineering Journal, 54, 745-756. http://dx.doi.org/10.1016/j.aej.2015.03.031

[21] Li, L.H., Sun, Y.M., Yuan, Z.H., Kong, X.Y. and Li, Y. (2013) Effect of Temperature Change on Power Generation of Microbial Fuel Cell. Environmental Technology, 34, 1929-1934. http://dx.doi.org/10.1080/09593330.2013.828101

\section{Submit or recommend next manuscript to SCIRP and we will provide best service for you:}

Accepting pre-submission inquiries through Email, Facebook, Linkedin, Twitter, etc

A wide selection of journals (inclusive of 9 subjects, more than 200 journals)

Providing a 24-hour high-quality service

User-friendly online submission system

Fair and swift peer-review system

Efficient typesetting and proofreading procedure

Display of the result of downloads and visits, as well as the number of cited articles

Maximum dissemination of your research work

Submit your manuscript at: http://papersubmission.scirp.org/ 